\title{
PPM1D Gene Mutation
}

National Cancer Institute

\section{Source}

National Cancer Institute. PPM1D Gene Mutation. NCI Thesaurus. Code C156760.

A change in the nucleotide sequence of the PPM1D gene. 